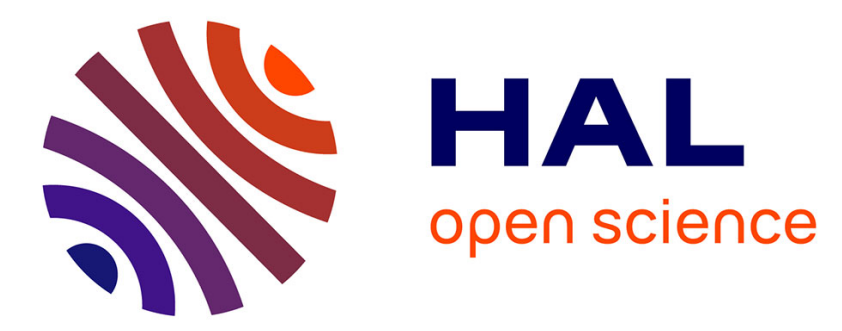

\title{
Antigen-antibody selective recognition using LiTaO SH-SAW sensors: investigations on macromolecules effects on binding kinetic constants
}

\author{
Y. Bergaoui, C. Zerrouki, N. Fourati, J. M. Fougnion, A. Abdelghani
}

\section{- To cite this version:}

Y. Bergaoui, C. Zerrouki, N. Fourati, J. M. Fougnion, A. Abdelghani. Antigen-antibody selective recognition using LiTaO SH-SAW sensors: investigations on macromolecules effects on binding kinetic constants. European Physical Journal: Applied Physics, 2011, 56 (1), pp.13705. 10.1051/epjap/2011100225 . hal-00736288

\section{HAL Id: hal-00736288 \\ https://hal.science/hal-00736288}

Submitted on 28 Sep 2012

HAL is a multi-disciplinary open access archive for the deposit and dissemination of scientific research documents, whether they are published or not. The documents may come from teaching and research institutions in France or abroad, or from public or private research centers.
L'archive ouverte pluridisciplinaire HAL, est destinée au dépôt et à la diffusion de documents scientifiques de niveau recherche, publiés ou non, émanant des établissements d'enseignement et de recherche français ou étrangers, des laboratoires publics ou privés. 


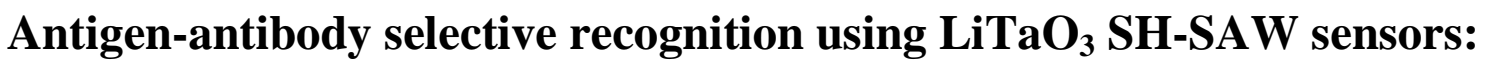 investigations on macromolecules effects on binding kinetic constants
}

\section{Shortened version: Antigen-antibody selective recognition using $\mathrm{LiTaO}_{3} \mathrm{SH}-\mathrm{SAW}$ sensors}

\author{
Y. Bergaoui ${ }^{1}$, C. Zerrouki ${ }^{2}$, N. Fourati ${ }^{2}$, J.M. Fougnion ${ }^{2}$ and A. Abdelghani ${ }^{1}$ \\ ${ }^{1}$ Unité de Recherche de Physique des Semiconducteurs et Capteurs, IPEST, 2070, La Marsa, Tunisia \\ ${ }^{2}$ Laboratoire de Physique, EA 4131, Cnam, 2 rue Conté, 75003 Paris, France \\ Emails : yosri_bergaoui@yahoo.fr - zerrouki@cnam.fr - fourati@cnam.fr - \\ fougnion@cnam.fr $-\underline{\text { aabdelghan@ @ yahoo.fr }}$
}

\begin{abstract}
A gravimetric surface acoustic wave (SAW) biosensor, based on the biotin-streptavidin and antistreptavidin-streptavidin recognitions, has been carried out. A network analyser and a pulse excitation technique were used to monitor both amplitude and phase changes.

The SAW biosensor presented a total selective recognition of streptavidin-antistreptavidin and HRPstreptavidin-antistreptavidin. The presence of HRP (Horseradish peroxidase) affects neither the selectivity nor the sensitivity (of order of $0.25 \% \mathrm{nM}$ ) of the biosensor, nevertheless, it causes a reduction of binding kinetics by a factor ranging between 2 to 5 , as well as a diminution of antistreptavidin saturation concentration (of $40 \%$ ). Results showed that equilibrium constants can be different, depending on evaluation method (from saturation values or from linear part of the output signal variation according to solution concentration).
\end{abstract}

Keywords: Surface Acoustic Wave sensor (SAW), antigen-antibody recognition, binding constants, reaction kinetics

\section{Introduction}

Surface acoustic waves sensors (SAW sensors), whose principle is based on variations of propagation media properties, were largely used for gas detection [1,2], and have recently revealed their great potential for chemical and biological species detection in liquid media [3-9]. These devices are still subjected to many technological developments, offering thus new prospects for label free detection of increasingly small quantities in real time. 
Because of their high mass sensitivity, SAW devices are among the most attractive sensors for biological applications, particularly as DNA biosensors [10, 13] and as immunosensors [14-16], based on the highly specific binding between antibodies and their corresponding antigens. The development of a specific biorecognition surface on a solid/liquid interface is of high significance in the areas of drug screening, proteomics, and biosensors. A primary challenge in developing such an interface is the design of a biorecognition layer that will possess the desirable properties of specificity, biocompatibility, and reversibility of the binding event [17].

Achieving an immunosensor involves the immobilization of an antigen (antibody) as bioreceptor, the antibody (antigen) being the ligand. Many methods have been used to immobilize the bioreceptor probe on the biosensor surface [18], but the most robust uses biotinylated self-assembled monolayer [19]. Grafting a specific layer on the sensor sensitive area constitutes a key stage, which makes the biosensor selective to particular molecules. The success of this stage determines the performances of the achieved sensor.

The goal of this study is the development of an immunosensor combining the sensitivity of gravimetric transduction, and affinity between several molecules: biotine/streptavidine/antistreptavidine (antistreptavidine was from a rabbit) and biotine/HRPstreptavidine/antistreptavidine (HRPstreptavidine being a streptavidine associated to horseradish peroxidase). The various biosensor realization steps and temporal follow-up of sensor's response in each case will be presented. Effects of macromolecules presence will be discussed, before evaluating equilibrium and association constants.

\section{Experimental setup and materials}

\subsection{SAW sensor design}

Among the variety of available non-labelled sensors, the most promising ones are the SAW devices since they are able to independently extract the pure mass and viscosity signal of a deposited layer [20]. The developed sensor consists of a dual delay line fabricated on a $36^{\circ}$ rot Lithium tantalate $\left(\mathrm{LiTaO}_{3}\right)$ piezoelectric substrate. Chromium/gold $(20 \mathrm{~nm} / 80 \mathrm{~nm})$ interdigital transducers (IDTs) were photolithographically patterned with a periodicity of $\lambda=40 \mu \mathrm{m}$ which corresponds to an operating frequency of about $104 \mathrm{MHz}$. Each electrode consists of 30 double finger pairs, minimising thus triple transit interferences, as observed for the simple finger pairs first prototype [10]. Two shear horizontal acoustic waves propagate on $\mathrm{LiTaO} 36^{\circ}$ rot: surface skimming bulk waves (SSBW) and leaky SAWs (LSAW). Metallization of the sensing area (the region between the IDTs) with 20/80 $\mathrm{nm} \mathrm{Cr} / \mathrm{Au}$ thin layer, favours leaky SAWs propagation [21, 22]; the acoustic energy is thus confined close to surface substrate, making the sensor highly sensitive to any perturbation occurring in the propagating medium. Gold metallization permits also to provide a suitable surface for molecules grafting and to make 
devices less sensitive to ionic strength variations. At this effect, we have tested the SAW response to $\mathrm{NaCl}$ solutions (from $0.1 \mathrm{M}$ to $1 \mathrm{M}$ ), and no change occurred, as expected.

For successful uses of SAW devices in liquid media, a fluidic cell has been designed: a Kalrez ${ }^{\circledR}$ cell is placed over the sensing area to contain solutions and to insure interdigitated transducers insulation (Fig.1). Kalrez ${ }^{\circledR}$ was chosen among other materials for its biocompatibility and mainly for its "nature" since it doesn't stick to the sensing area, like PDMS, and doesn't need an additional joint like PMMA. It causes an additional attenuation of the surface wave of only $5 \mathrm{~dB}$ at the fundamental frequency of $104 \mathrm{MHz}$. A PMMA sill including inlets and outlets is then added. Experiments were driven using peristaltic pump (Gilson Minipuls 3) to insure continuous fluids flow at a $190 \mu \mathrm{L} / \mathrm{min}$ rate.

In order to cancel temperature and pressure fluctuations, a dual-delay-line configuration was used: the delay lines are inserted in a pulse mode system with two independent paths. The measured parameter is phase and/or amplitude shifts of the sensing line according to the reference one. A HF generator carries out a $104 \mathrm{MHz}$ frequency signal, which is modulated via a HF amplifier, by means of a rectangular pulse signal generator (pulses trains frequency is about $10 \mathrm{kHz}$ and their width is adjusted between 1.5 and $2 \mu \mathrm{s}$ ). The resulting signal is then applied to the sensor input. The output signal is then injected into a comparator to estimate its phase and amplitude variations, according to the original HF signal. A "boxcar integrator" synchronized on the pulse signal generator, permits to select the useful signal (according to its delay) and to send it (averaged and integrated over fixed duration) into a digital analogical converter.

In parallel, HP 8711C network analyzer has been used to measure amplitude and phase variations of the output electrical signal.

\subsection{Chemical and biochemical reagents}

1,2-dipalmitoyl-sn-glycero-3-phosphoethanolamine- $N$ - (biotinyl) (biotinyl-PE) was from Avanti polar lipids. 16-mercaptohexadecanoic acid (MHDA), bovine serum albumin (BSA) blocking agent, streptavidin, rabbit anti-streptavin and immunoglobulin G (IgG) sheep were purchased from SigmaAldrich and HRP-streptavidin was from Serotec.

For all biosensing experiments, the buffer solution ( $\mathrm{pH}$ 7.4) was a phosphate buffered saline (PBS) containing $140 \mathrm{mM} \mathrm{NaCl}, 2.7 \mathrm{mM} \mathrm{KCl}, 0.1 \mathrm{mM} \mathrm{Na} 2 \mathrm{HPO}_{4}, 1.8 \mathrm{mM} \mathrm{KH}_{2} \mathrm{PO}_{4}$. All reagents were of analytical grade, and ultrapure water (resistivity of $18.2 \mathrm{M} \Omega . \mathrm{cm}^{-1}$ ) produced by a Millipore Milli-Q system was used. Before any experiment, SAW devices were immersed for 30 min into a piranha solution (1:1 (v/v) 98\% $\mathrm{H}_{2} \mathrm{SO}_{4} / 30 \% \mathrm{H}_{2} \mathrm{O}_{2}$ ), then rinsed with ultra pure water and immediately dipped in a methanol solution. Despite its drastic character, this procedure allows to obtain a clean and preactivated surface, suitable for the next operations. 


\section{Biosensor realisation}

\subsection{Self assembled monolayer formation}

Various successive steps must be carried out on the sensing area of the gold metalized delay line, to obtain an antibody/antigen sensor. The first one consists on the grafting of biotinylated self-assembled monolayer. Primary, a methanol solution is brought on the sensing area using the peristaltic pump. When phase stability is reached, a continuous flow of a mixed solution of MHDA (1 mM) and biotinyl-PE $(0.1 \mathrm{mM})$ is pumped. A mixed self-assembled monolayer (SAM) is thus formed and permits the development of an efficient surface chemistry for the immobilization of antibodies onto gold surfaces. As mentioned in our previous works [23, 24], the formation of this SAM requires nearly 10 hours.

After rinsing the device with ultra pure water, a BSA solution $(0.2 \%, \mathrm{w} / \mathrm{v})$ was drained into the flow cell, at room temperature, in order to block free spaces between biotin molecules. A subsequent rinsing with PBS permits to remove non fixed BSA. Results presented in Fig. 2 show that this layer formation generates a phase variation of $2.2^{\circ}$ in 40 minutes only.

\subsection{Streptavidin immobilisation as antibody}

A solution of $5 \mu \mathrm{l} / \mathrm{ml}$ of streptavidin - antibody in PBS was then injected in the flow cell and let in circulation until the signal became stable. A final rinse with PBS permits to remove unbound streptavidin. In the same way, we have also immobilised a Horseradish peroxidase conjugated streptavidin (HRPstreptavidin) to check the SAW sensors response in the presence of macromolecules, able to cause steric effects.

Similarly to previously described steps (BSA and SAM layers formations), biotin-HRPstreptavidin and biotin-streptavidin recognitions have been monitored via phase variation versus time (Fig. 3). The first injections of HRPstreptavidin solution $(2.5 \mathrm{nM}$, then $5 \mathrm{nM}$ ) lead to cumulated phase variations of about $1^{\circ}$. Fig. 3 shows also that the reaction is fast, the output signal stabilization being reached at $600 \mathrm{~s}$ approximately. Successive additions made it possible to determine the sensor's linearity range, up to $10 \mathrm{nM}$, for which the sensitivity was estimated at $0.25^{\circ} / \mathrm{nM}$.

\subsection{Antibody-antigen selective recognition}

To test the sensor's selectivity, we have used an anti-streptavidin produced in rabbit as a specific antigen and an IgG sheep as a non specific one. First, $1.66 \mathrm{nM}$ of anti-streptavidin were injected in the flow cell leading to phase shift of about $0.4^{\circ}$, which is characteristic of antistreptavidin-streptavidin (antistreptavidin-HRPstreptavidin) recognition (Fig. 4). After that, and once the signal stability reached, $1.66 \mathrm{nM}$ of $\operatorname{IgG}$ sheep were added. No signal variation occurred showing that there is no recognition between antibody and the non specific antigen. The experiment was repeated many times 
until sensor's saturation, and the same results were obtained confirming the sensor's selectivity. This signifies that in spite of the presence of the HRP, the streptavidin-antistreptavidin recognition sites remain accessible. The sensor's sensitivity also isn't affected by macromolecules presence. Values of $(0.21 \pm 0.10)^{\circ} / \mathrm{nM}$ and $(0.22 \pm 0.09)^{\circ} / \mathrm{nM}$ were obtained without and in presence of HRP, respectively. Nevertheless, the effect of HRP appears clearly on antigen concentration saturation values: $(23 \pm 2) \mathrm{nM}$ and $(10 \pm 2) \mathrm{nM}$ in absence and presence of HRP respectively (Fig. 5). Another effect can be shown on recognition reactions kinetics as it will be mentioned in the next paragraph.

\section{Recognition reaction Kinetics, results and discussions}

Analysis of antibody-antigen recognition reactions kinetics, in presence and in absence of HRP, showed differences as observed on Fig. 6, where phase variations versus time during HRPstreptavidinantistreptavidin and streptavidin-antistreptavidin recognitions are compared. Results show that conjugating streptavidin with Horseradish peroxidase increases sensor's output stabilization time from $1000 \mathrm{~s}$ to $2000 \mathrm{~s}$. Moreover, and by using an exponential decay as model, we can extract time constant of the two reactions. Much important difference was found between the two constants: $140 \mathrm{~s}$ with HRP and $30 \mathrm{~s}$ without HRP.

Another approach to analyse kinetics is given by the equation $1[19,20]$ :

$$
\frac{d \phi}{d t}=K_{o n}[a n t i-s a v]\left(\phi_{\max }-\phi\right)-k_{o f f} \phi
$$

Where $\phi$ is the acoustic phase; [anti-sav] is the antigen concentration; $k_{o n}$ and $k_{\text {off }}$ are the association and dissociation constants.

Using numerical approach, equation 1 becomes:

$$
\Delta(d \phi / d t) / \Delta \phi=K_{o n}[a n t i-s a v]+k_{o f f}
$$

Plots representing equation 2 (Fig. 7), permit an experimental estimation of both $k_{o n}$ and $k_{o f f}$, then the equilibrium constant: $k_{e q}=k_{o n} / k_{o f f}$.

Only data corresponding to the sensor linearity range are considered there. The obtained values are gathered in table 1. 
Table 1: Experimental values of binding constants

\begin{tabular}{l|c|c|c} 
Binding reactions & $k_{\text {on }}\left[\mathrm{M}^{-1} \mathrm{~s}^{-1}\right]$ & $k_{\text {off }}\left[\mathrm{s}^{-1}\right]$ & $K_{\text {eq }}\left[\mathrm{M}^{-1}\right]$ \\
\hline Anti-sav/sav & $1.910^{5}$ & $2.210^{-4}$ & $8.610^{8}$ \\
\hline Anti-sav/HRPsav & $5.710^{4}$ & $9.310^{-5}$ & $6.110^{8}$ \\
\hline
\end{tabular}

The equilibrium constant $k_{e q}$ can also be determined starting from saturation values, by considering the Langmuir equation which traduces the concentration dependence on the signal phase shift [14]:

$$
\phi([C])=\frac{\phi_{s a t}[C]}{[C]+1 / k_{e q}}
$$

Where $\phi_{\text {sat }}$ corresponds to the maximum phase shift (saturation value).

The experimental determination of $k_{e q}$ leads to: $k_{e q}=6.710^{8} \mathrm{M}^{-1}$ for streptavidin-antistreptavidin and $k_{e q}=2.210^{8} \mathrm{M}^{-1}$ for HRPstreptavidin-antistreptavidin. The first value of $k_{e q}$ is consistent (within uncertainties) with this determined from linear range measurements, but the second one is different enough, due to the saturation value which is affected by HRP presence.

\section{Conclusion}

In this study we have carried out a gravimetric surface acoustic wave biosensor based on biotinestreptavidine and antistreptavidine - streptavidine recognitions. We have showed that grafting several molecular "layers" on the SAW sensing area doesn't affect neither sensitivity nor streptavidineantistreptavidine recognition, in presence or not of the Horseradish peroxidase (HRP). However, the presence of HRP causes a steric effect that leads to a reduction of both antigen concentration saturation value and the kinetic constant $\mathrm{k}_{\mathrm{eq}}$. The obtained results, mainly the high affinity and specificity of antigen-antibody interactions, show the potential of developing SAW immunosensors for biomolecular interactions, especially in the field of clinical analysis. The relatively easy construction of a specific biological assembly on the SAW sensors can so supply a wide variety of bio-recognition, such as DNA, RNA, antibodies or proteins (indicators of viral infection), with concentrations lower than $1 \mathrm{nM}$. 


\section{References}

1. C. Dejous, D. Rebière, J. Pistré, C. Tiret, R. Planade, M. Hoummady, Sens. Actuators B. 24, 58 (1995).

2. M. Rapp, J. Reibel, A. Voigt, M. BAlzer, O. Bulow, Sens. Actuators B. 65, 169, (2000).

3. F. Josse, F. Bender, R. W. Cernosek, Anal. Chem. 73, 5973 (2001).

4. Z. Li, Y. Jones, J. Hossenlopp, R. Cernosek, and F. Josse, Anal. Chem. 77, 4595 (2005).

5. W. Welsch, C. Klein, R. M.oksuzoglu, M. von Schickfus, Sens. Actuators A 62, 562 (1997).

6. J. Andra, A. Bohling, T.M. A. Gronewold, U. Schlecht, M.Perpeet, T. Gutsmann, Langmuir, 24, 9148 (2008).

7. E. Gizeli, C.R Lowe., Biomolecular Sensors, (Lowe Eds. Taylor \& Francis, 2002).

8. G.Hua, J.Xub, G.W.Auner, J.Smolinski, H.Ying, Sens. Actuators B., 132, 272 (2008).

9. A.Malavé, U.Schlecht, T. M. Gronewold, M. Perpeet, M. Tewes, IEEE SENSORS, EXCO, Daegu, Korea, 604 (2006)

10. N. Fourati, M. Lazerges, C. Vedrine, J.M. Fougnion, C. Zerrouki, L. Rousseau, P. Lepeut, J.J. Bonnet and C. Pernelle, Sens. letters, 7, 847 (2009).

11. J. Sakong, H. Roh, Y. Roh, Japanese Journal of Applied Physics, 46, 4729 (2007).

12. C. Zerrouki, N. Fourati, R. Lucas, J. Vergnaud, J.M. Fougnion, R. Zerrouki, C. Pernelle, Biosens. Bioelectronics, 26, 1759, (2010).

13. C. Zerrouki, N. Fourati, M. Lazerges, J.M. Fougnion, C. Vedrine, C. Pernelle, Sensor Letters, 8, 813 (2010).

14. E. Gizeli , F. Bender , A. Rasmusson , K. Saha , F. Josse , R. Cernosek, Biosens. and Bioelectronics, 18, 1399 (2003).

15. E. Gizeli, M. Liley, C. R. Lowe, and H. Vogel, Anal. Chem., 69, 4808 (1997)

16.Y. Roh, Y. Hur, Y.E. Pak, IEEE Ultrasonics Symposium, 817 (2004).

17. E. Gizeli, J. Glad, Anal. Chem, 76, 3995 (2004).

18. W.Welsch, C.Klein, M.von Schickfus, S. Hunklinger, Analytical Chemistry, 68, 2000 (1996).

19. M. Schaferling, M. Riepl, P. Pavlickova, H. Paul, D. Kambhampati, B. Liedberg, Microchim. Acta 142, 193 (2003).

20. A. Tsortos, G.Papadakis, K.Mitsakakis, K. A. Melzak,. E. Gizeli, Biophys. J., 94, 2706 (2008).

21. K-Y. Hashimoto, (Springer, Berlin, 2000).

22. Harding, G. L., Du, J., Smart Mater. Struct. 6, 716 (1997).

23. C. Esseghaier, Y. Bergaoui, H. ben Fredj, A. Tlili, S. Helali, S. Ameur, A. Abdelghani, Sens and Actuators B. 134, 112 (2008).

24. Y. Bergaoui, J.M. Fougnion, N. Fourati, C. Zerrouki, A. Abdelghani, C2I 2010, (Edition HermèsLavoisier, 2010) p. 91. 

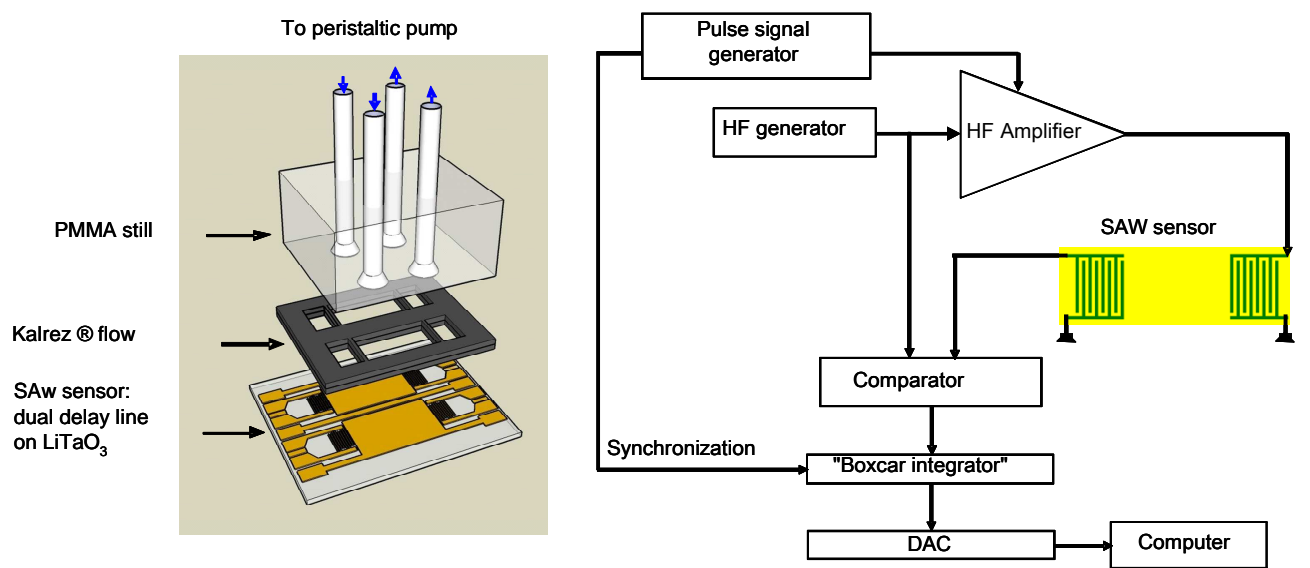

Fig. 1. Schematic representations of the various parts of the sensing system (left) and pulse mode system diagram (right). 


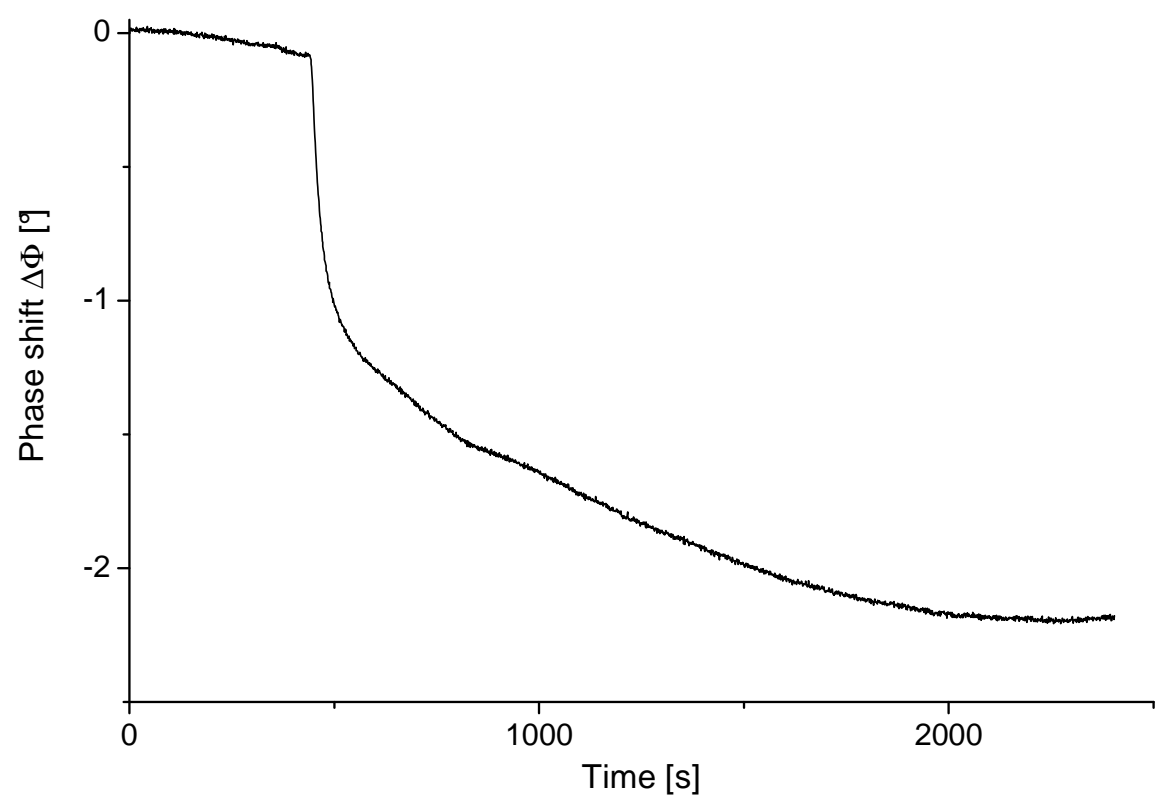

Fig. 2. Phase variations versus time during BSA adsorption. 


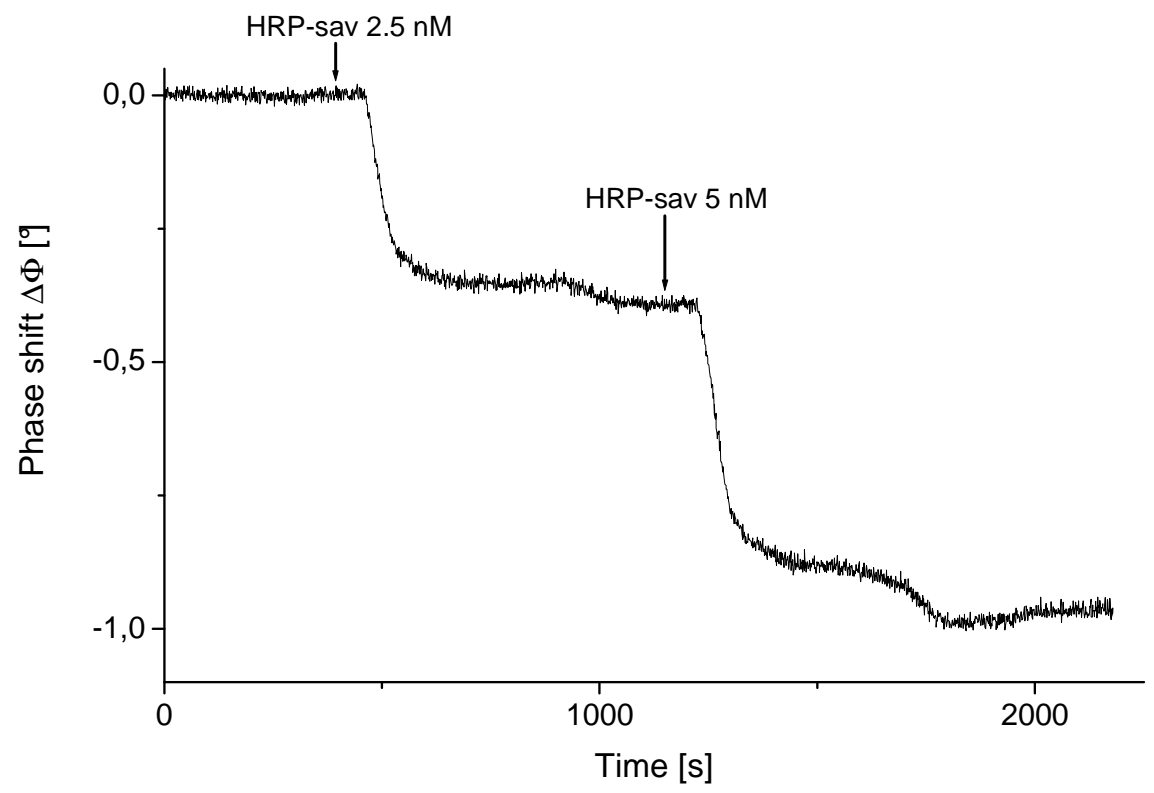

Fig. 3. Phase variation versus time, during biotin-HRPstreptavidin recognition. 


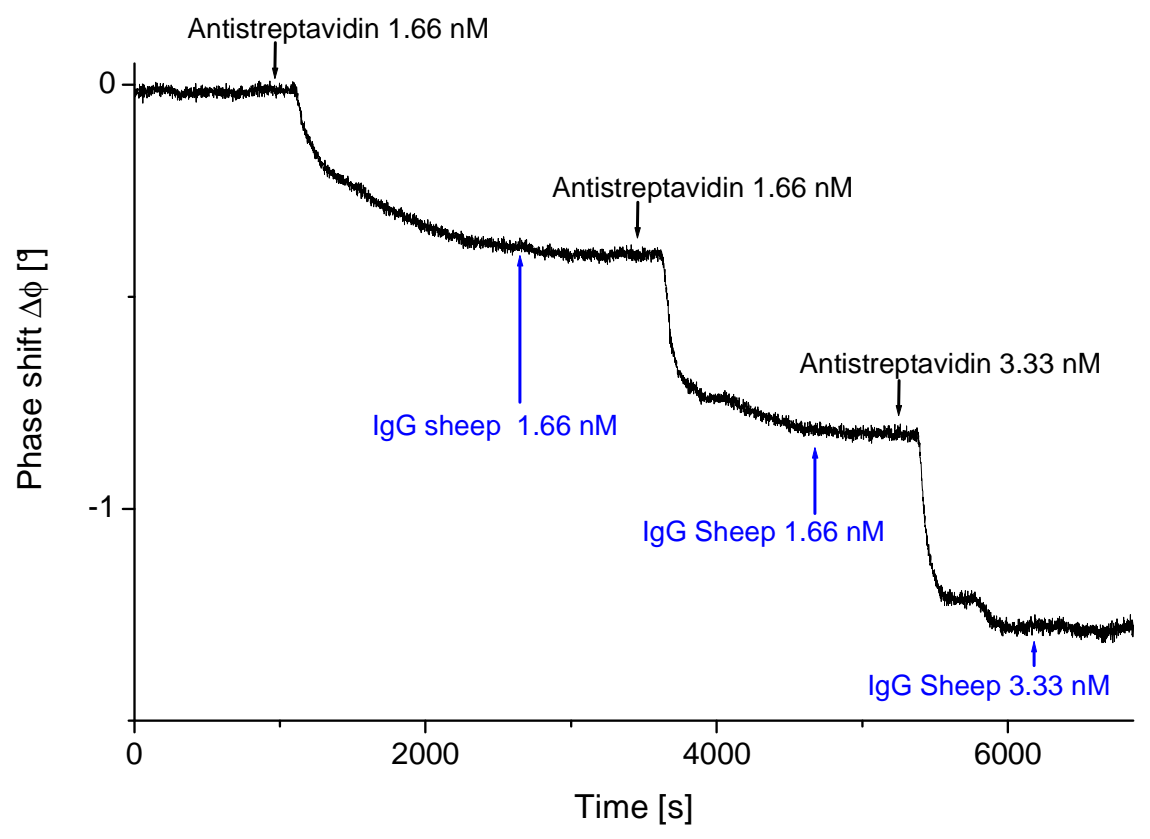

Fig. 4. Phase variation versus time, during antistreptavidin-streptavidin recognition, and signal stability after IgG sheep injections. 

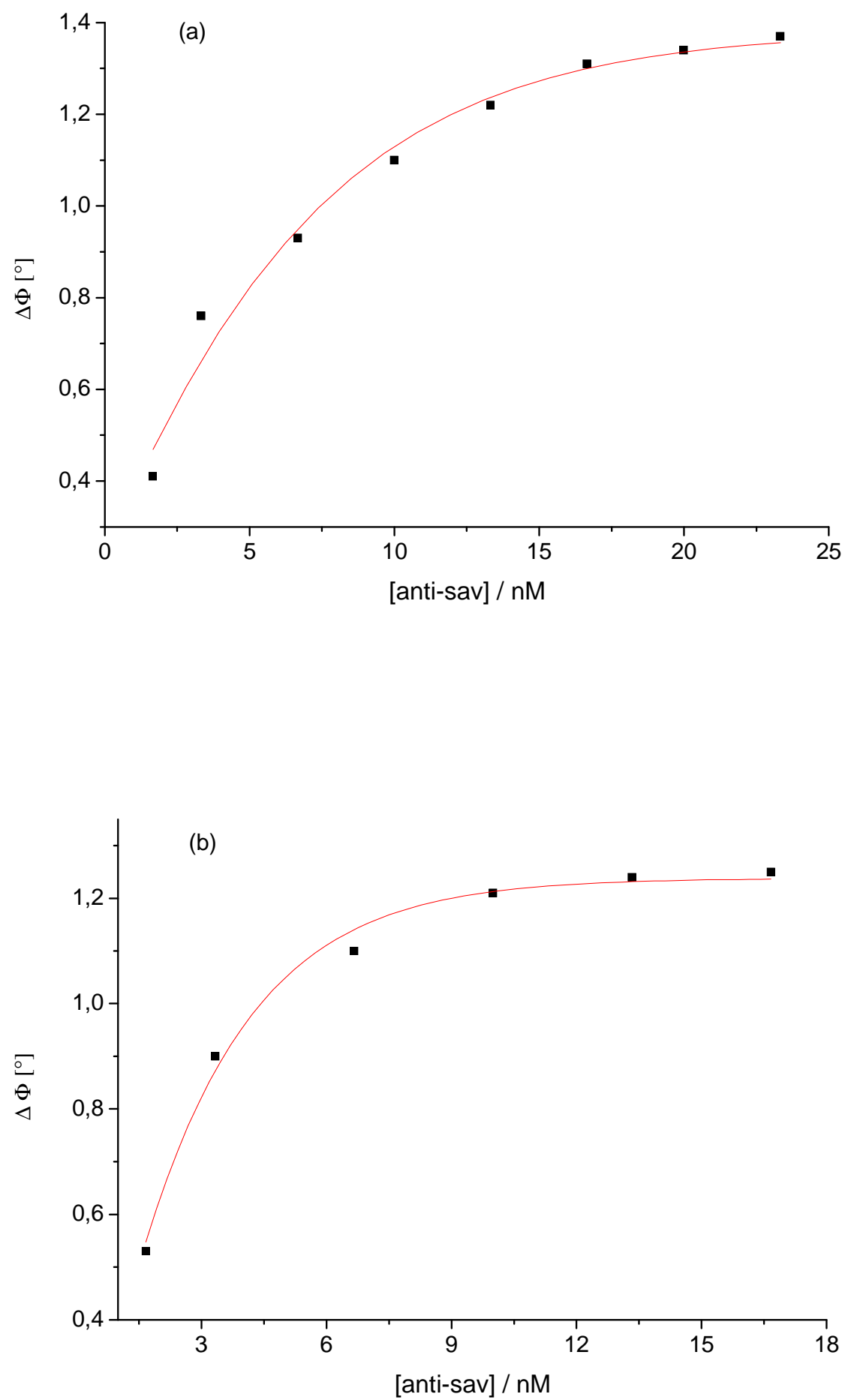

Fig. 5. Phase variation versus antistreptavidin concentration a)without HRP, b) in presence of HRP. 


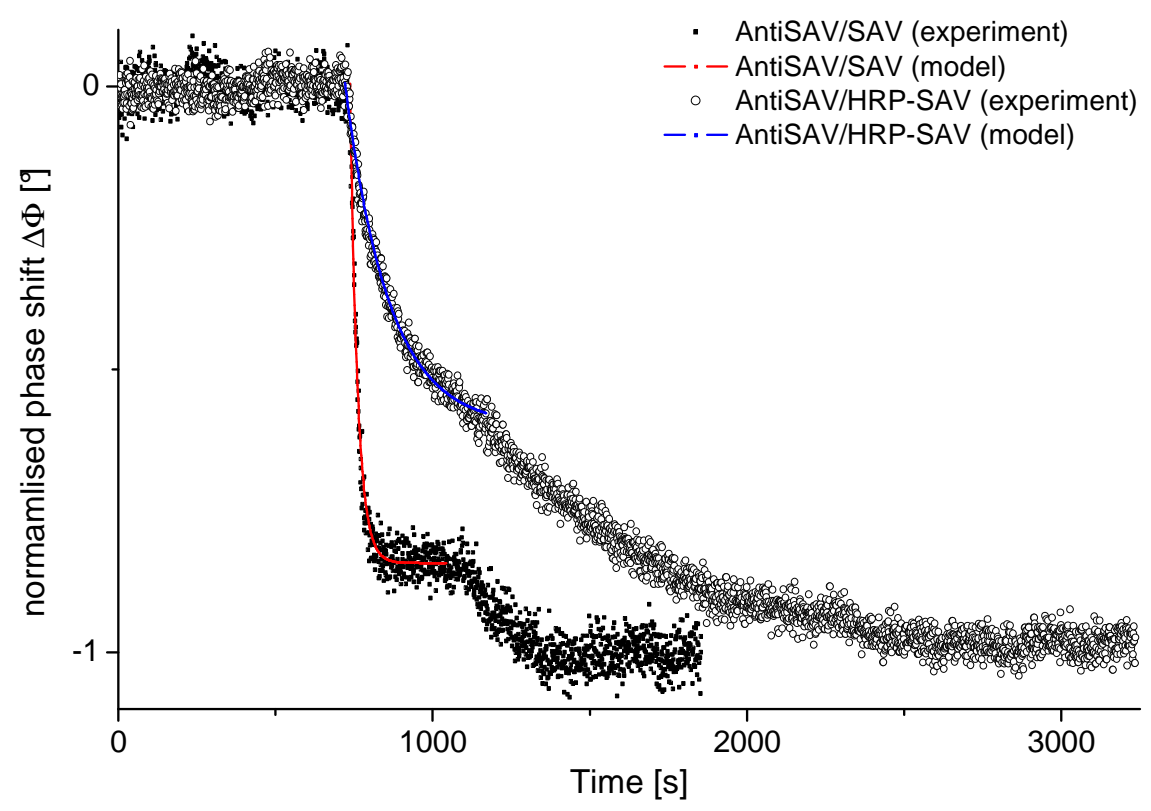

Fig. 6. Comparison of recognition reaction times of antistreptavidin-streptavidin and antistreptavidinHRPstreptavidin. Model is used for the first parts of the two plots to extract time constantans. 

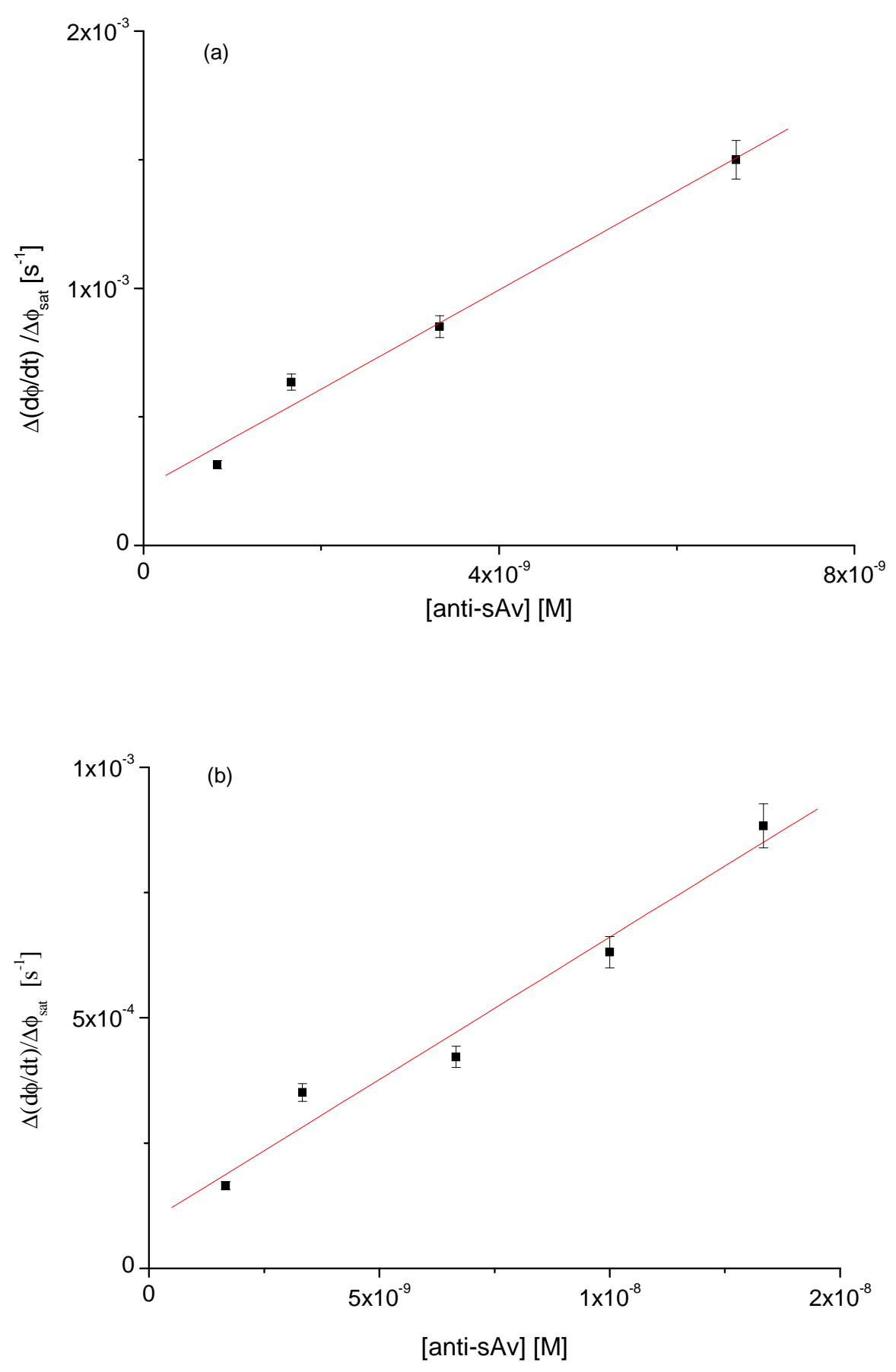

Fig. 7. Binding constants determination from kinetics analysis of recognition a) antistreptavidinstreptavidin and b) antistreptavidin-HRPstreptavidin. 